\title{
Determinants of Entrepreneurial Intention among Higher National Diploma Students of Polytechnics in Bauchi State
}

\author{
Abdulazeez, Khadijat Bolaji (PhD) \\ Office Technology and Management Department, Federal Polytechnic, Bauchi, Nigeria
}

DOI - http://doi.org/10.37502/IJSMR.2022.5104

\begin{abstract}
The study was carried out to determining entrepreneurial intentions of students in tertiary institutions. Sample size of 260 respondents using Morgan table for sample size was used to select sample size out of the population of 818 students from Federal Polytechnic Bauchi. The design of the study was a descriptive survey in which a group of individual's items were studied by collecting and analyzing data from a few population or items considered to be a representative of the entire population using Morgan Table for determining sample size. A 45 structure questionnaire, namely MVEIQ (Modified Version of Entrepreneurial Intention) was used to measure their agreement level. Data collected were analyzed using percentage, mean and standard deviation for the research questions. The findings of the study revealed that Higher National Diploma student's demographic characteristics, attitude, subjective norms, perceived behaviour, closer valuation and social valuation have influence on their entrepreneurial intentions. The hypothesis tested using multiple regression at 0.05 level of significance revealed that, there were significant contribution of the variables in the model. Base on the findings therefore, it was recommended that, all the stakeholder such as government agency, policy makers, school authorities, and parents should create enabling environment that will help the Higher National Diploma students' developed positive attitude towards entrepreneurial intentions.
\end{abstract}

Keywords: Education, Entrepreneurship education, Entrepreneurial Intention.

\section{Introduction}

Education, according to Oyebola (2014) is defined as a process of socialization in which an individual acquires values, standards norms and knowledge to enable him leaved a productive life in the society. The National Policy on Education 2004 was developed to prepare graduates to successes in an entrepreneurial economy. Decree 33 of 1979 stated that "polytechnic education as higher institutions was set up primarily to produce higher and lower technician manpower for the national economy". Thus, by its establishment, government desires that the nation's drive towards technological development would be attained at a somewhat fast pace through polytechnic education that it's graduates should prove themselves worthy men and women who are able to use their brains as adeptly as they can apply hands these ideals must be reflected in types of training and knowledge graduates 
are exposed to, all in a desire to build a dynamic and prosperous nation. Fakae, (2005) asserted that "emphasis which was on skill-acquisition and sound scientific knowledge, which gives ability to the use of hand and machines for the purpose of production, maintenance and self-reliant". Despite these well-articulated policies, the problem remains very conspicuous. The high unemployment has leading to increasing poverty and serious social problems in Nigeria. Although some modification has been made with time to reflect changing demands, little or no achievement has been recorded in ameliorating the diverse social economic problems in the country while higher education policy as stipulated in the National Policy on Education (NPE) is expectedly to cater for production scientist and technologist and absolutely none was directed for self employment (Aladekomo, 2004). Similarly, Polytechnics students' are trained as preparation to enter the business world according to their areas of study. However, they would be officers or entrepreneurs after graduation would be determined by their intent. An intention is an anticipated outcome guided by planned actions that predict deliberate behaviour which assumed to take hold of emotional factors that influences behavior and indicate one's efforts trying to perform intentional behavior which involves cognitive process that has to do with belief, perception and action (Ajzen, 1991). Therefore, Starting a business by polytechnic student's require gradual process which involve intention to start, conception of business idea and the actual formation of the business. Entrepreneurship activity is a planned behavior which is intentional and usually affected by individual's intention (Krueger and Carsrud, 2005)

\section{Literature Review}

\subsection{Concept of Entrepreneurship Education}

Entrepreneurship is the practice of starting new organizations, particularly new businesses generally in response to identified opportunities. According to Schumpeter, Entrepreneurship is the 'spirit' to innovate. Hart, Stevenson Knight, Drucker, and Dial (2007) have defined entrepreneurship as risk-taking behaviour which has been carried out for future benefit and gaining independence and self-control (Parker, 2004). An entrepreneur is a person who undertakes and operates a new enterprise or venture and assumes some accountability for the inherent risks. Therefore, virtually entrepreneurship is equivalent to starting new businesses (Wilberforce \& Fleming, 2001)

The term entrepreneurship education is used interchangeably with entrepreneurship training and skill acquisition. Conceptually, entrepreneurship education refers to a specialized knowledge that inculcate in learners the traits of risk-taking, innovations, arbitrage and coordination of factors of production for the purpose of creating new products or services for new and existing users within human communities Mauchi; et al assert that entrepreneurship education can be defined as the process of providing individuals with the ability to recognize commercial opportunities and the knowledge skills and attitudes to act on them.

The deliverables of entrepreneurship education when properly imbibed by students and learners are the ability to identify something happening in the environment (resources) and (b) ability to impart something new to trainees, so that their creativity, innovative abilities, 
beliefs and recombination skills would be enhanced (Fuduric 2008). Then entrepreneurship education can be described as a training that stimulates learners to better their lives by generating value through the creation or expansion of economic activity, identification and exploiting new products, processes or markets. Since entrepreneurship can be taught, entrepreneurship education refers to the programmatic and meaningful interaction between learner and instructor for the purpose of developing the ability of the learners to identify, evaluate and generate ideas and solving business problems in a unique way (Raimi 2011). Entrepreneurship education when effectively and efficiently taught has the likelihood to precipitate self-employment among learner and accelerating sustainable growth and development. This is evident in a number of developed nations like Japan and America that utilize entrepreneurial (facilitative) education for improving their human as opposed to the traditional approach of teaching and listen approach which is prevalent in the developing third world nation (Witte, Wolf \& Raimi et al 2011).

\subsection{Statement of the Problem}

Although entrepreneurial intention is an important field in entrepreneurship, the factors that determined entrepreneurial intention of tertiary institutions students still lacks empirical evidence (Choo and Wong, 2000' Davidsson, 1995). Similarly, Nabi, Linan, 2011; Sandhu, Sidique, \& Raiaz, (2011) Izedommi and Okafor, (2010) pointed out that only few studies were conducted on entrepreneurial intention in the developing countries. Specifically, Nigeria is lacking empirical researchers on entrepreneurial intention. Izeodnmi, (2010) also asserted that, despite the importance of entrepreneurship program to social and economic development of the nation, the role of students' in promoting entrepreneurship still remains largely unstudied Ofishe (2011) posted that to become an entrepreneur or a job creator one need to have some traits and character. He stated further that the traits, drives and character lead to innovation and the spirit of production are not in some of the tertiary institution students'. Despite these well articulated policies, the problem remains very conspicuous. It is against this backdrop that this study aimed to find out the factors that determine entrepreneurial intention among Higher National Diploma students in Bauchi State.

\subsection{Purpose of the Study}

The main purpose of this study was to find out the extent to which certain factors determined entrepreneurial intention among the Higher National Diploma students in Bauchi State. Specifically, the study sought to:

1. Determine demographic characteristics influence on Higher National Diploma students entrepreneurial intention.

2. Determine the extent to which attitude influence the entrepreneurial intention of Higher National Diploma students.

3. Find out the extent to which subjective norms influence the entrepreneurial intention of Higher National Diploma students.

4. Ascertained the extent to which perceived behavioural norms influence the entrepreneurial intention of Higher National Diploma students. 
5. Determine the extent to which closer valuation influence the entrepreneurial intention of Higher National Diploma students.

6. Find out the extent to which social valuation influence the entrepreneurial intention of Higher National Diploma students.

\subsection{Research Questions}

The following research questions were formulated and guided the study:

1. To what extent does a demographic characteristic influence Higher National Diploma student's entrepreneurial intention?

2. To what extent does attitude influence entrepreneurial intention of Higher National Diploma students?

3. To what extent does subjective norms influence entrepreneurial intention of Higher National Diploma students?

4. To what extent does perceived behavioural norms influence entrepreneurial intention of Higher National Diploma students?

5. To what extent does closer valuation influence entrepreneurial intention of Higher National Diploma students?

6. To what extent does social valuation influence entrepreneurial intention of Higher National Diploma students?

\subsection{Research Hypotheses}

The following Null Hypotheses were tested at 0.05 level of significance.

$\mathrm{Ho}_{1}$ Attitude has no significant influence on entrepreneurial intention of Higher National Diploma students.

Ho2 Subjective norms has no significant influence on entrepreneurial intention of Higher National Diploma students

Ho3 Perceived behavioural norms have no significant influence on entrepreneurial intention of Higher National Diploma students.

Ho4 Closer valuation has no significant influence on entrepreneurial intention of Higher National Diploma students

Ho5 Social valuation has no significant influence on entrepreneurial intention of Higher National Diploma students

\section{Methodology}

In this study, descriptive survey design was adopted for the study. The study was carried out to determining entrepreneurial intentions of Higher National Diploma students in Bauchi State. Sample size of 260 respondents was selected out of the population of 818 students from School of Business Studies. The design of the study was a descriptive survey in which a group of individual's items were studied by collecting and analyzing data from a few population or items considered to be a representative of the entire population. A 45 structure questionnaire, namely MVEIQ (Modified Version of Entrepreneurial Intention) was used to measure their agreement level. The data collected were analyzed using percentage, descriptive statistics (i.e. Mean) and inferential statistics (i.e. Multiple Regression Analysis). 
The study used five variables to ascertain extent of entrepreneurial intentions and to examine whether Higher National Diploma students vary in their self-employment intentions.

Table 1: Description of Scales in the MVEIQ and their classification and interpretation

\begin{tabular}{llll}
\hline S/N & Scale Point & Mean Scale & Indicators \\
\hline 1 & 5 & $4.50-5.00$ & Very High Extent \\
2 & 4 & $3.50-4.49$ & High Extent \\
3 & 3 & $2.50-3.49$ & Moderately Extent \\
4 & 2 & $1.50-2.49$ & Low Extent \\
5 & 1 & $1.00-1.49$ & Very Low Extent \\
\hline
\end{tabular}

4. Results

BIO DATA

Table 2: Frequency and Percentage of Demographic Characteristic of Higher National Diploma Students.

Table 1: Gender Distribution

\begin{tabular}{|l|c|l|}
\hline Category & Frequency & Percentages \\
\hline Male & 190 & 66.7 \\
\hline Female & 95 & 33.3 \\
\hline Total & 285 & 100 \\
\hline
\end{tabular}

Source: Field work 2021

From Table 2 results shows that 190(66.7\%) and 95(33.3\%) of the respondents were male and female respectively. This implies that, the total number of male respondents was greater than female respondents. This can be illustrated in the chart below.

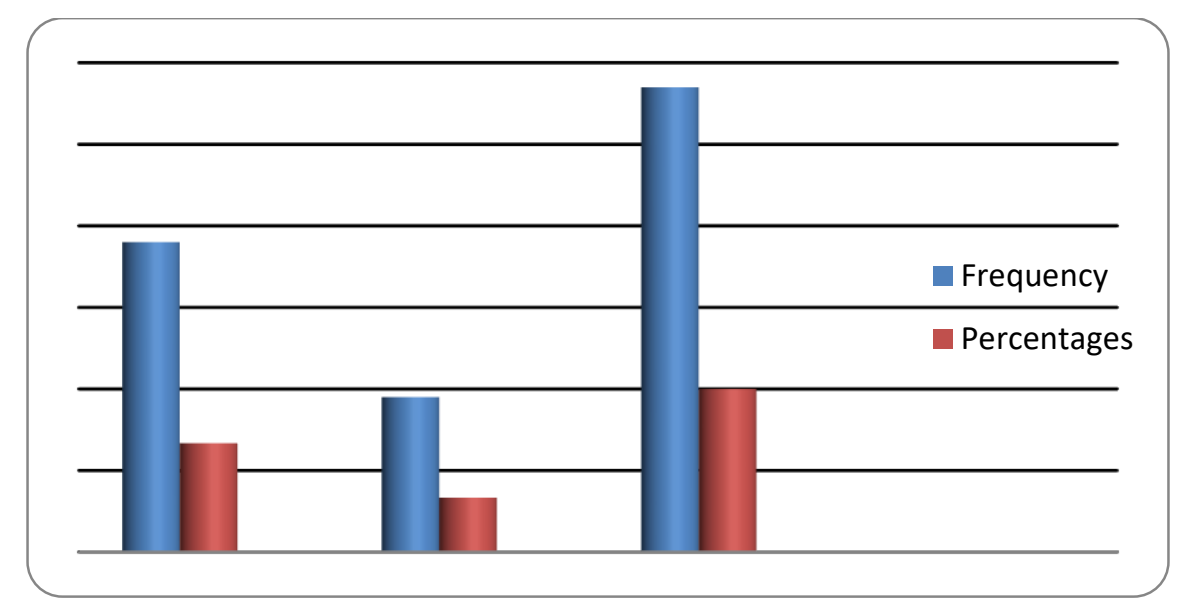

Fig 1:

Source: Field work 2021 
Table 2: Age Distribution

\begin{tabular}{|l|l|l|}
\hline Category & Frequency & Percentages \\
\hline $18-24$ & 184 & 64.5 \\
\hline $24-30$ & 88 & 31.9 \\
\hline Above 31 & 13 & 4.6 \\
\hline Total & 285 & 100 \\
\hline
\end{tabular}

Source: Field work 2021

Table 3 also revealed that the age range of 18-24, 25-30, Above 31 years accounts for $184(64.5 \%), 88(31.9 \%)$ and13(4.6\%). This shows age range of 18-24 years accounts for the highest, while age range of 45 and above years account for the lowest. The chart below illustrated it.

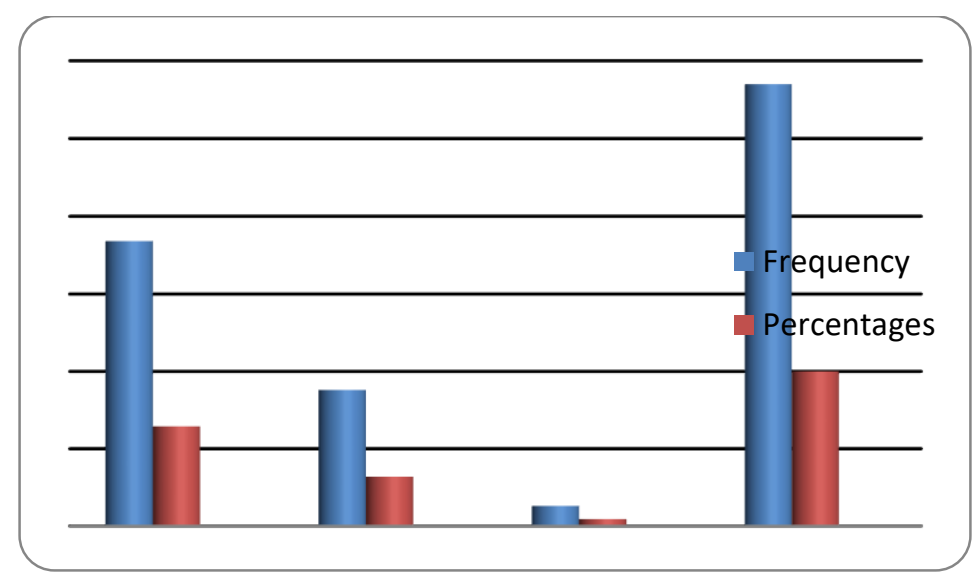

Fig 2:

Source: Field work 2021

Table 4. Educational Background

\begin{tabular}{|l|l|l|}
\hline Category & Frequency & Percentages \\
\hline SSCE & 142.5 & 50 \\
\hline ND & 142.5 & 50 \\
\hline Total & 285.0 & 100 \\
\hline
\end{tabular}

Source: Field work 2021

Table 4 shows individual background characterizes such as SSCE, 142.5 (50\%), ND 142.5 $(50 \%)$ were the frequency and percentage of respondents from the educational background of the students. This shows that most of the respondents in this exercise had SSCE and ND. This also will be illustrated on the chart below. 


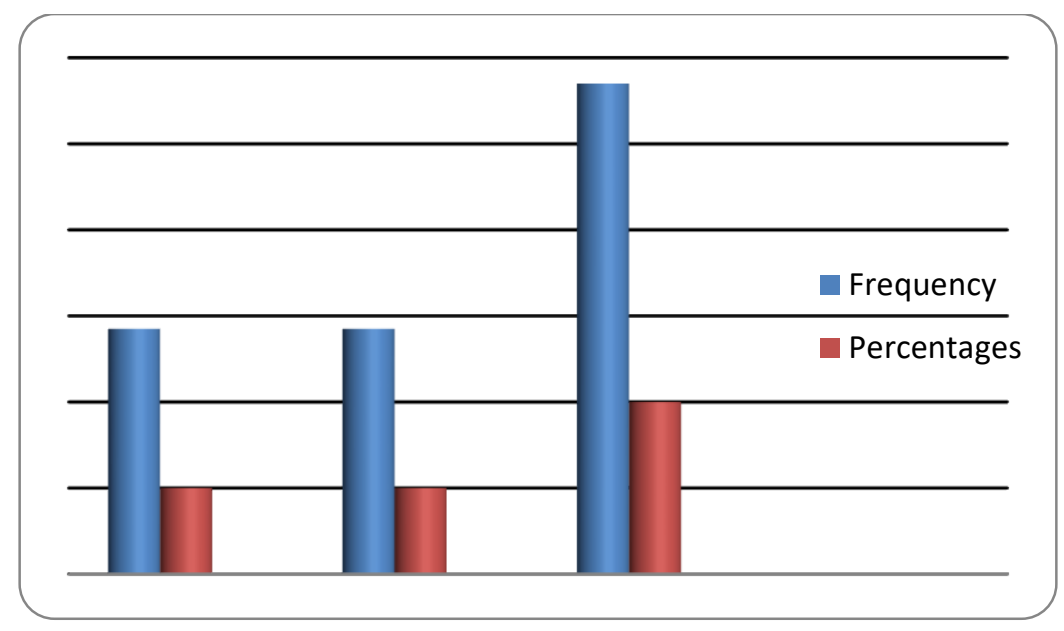

Fig 3:

Source: Field work 2021

Table 5: Employment Experience/Industrial Attachment

\begin{tabular}{|l|c|c|}
\hline Category & Frequency & Percentages \\
\hline Public sectors & 90 & 31.6 \\
\hline Private sectors & 177 & 62.1 \\
\hline Others & 18 & 6.3 \\
\hline Total & 285 & 100 \\
\hline
\end{tabular}

Source: Field work 2021

Table 5 shows the employment experience of the students ranging from private sectors experience of the students shows $90(31.6 \%)$, public sectors has $177(62.1 \%)$ while other has $18(6.3 \%)$, private sector experience and both sectors experience shows the number of involvement and role of the graduates in new venture creation. The total number of private experience" was greater than public sectors experience. The chart illustrated it.

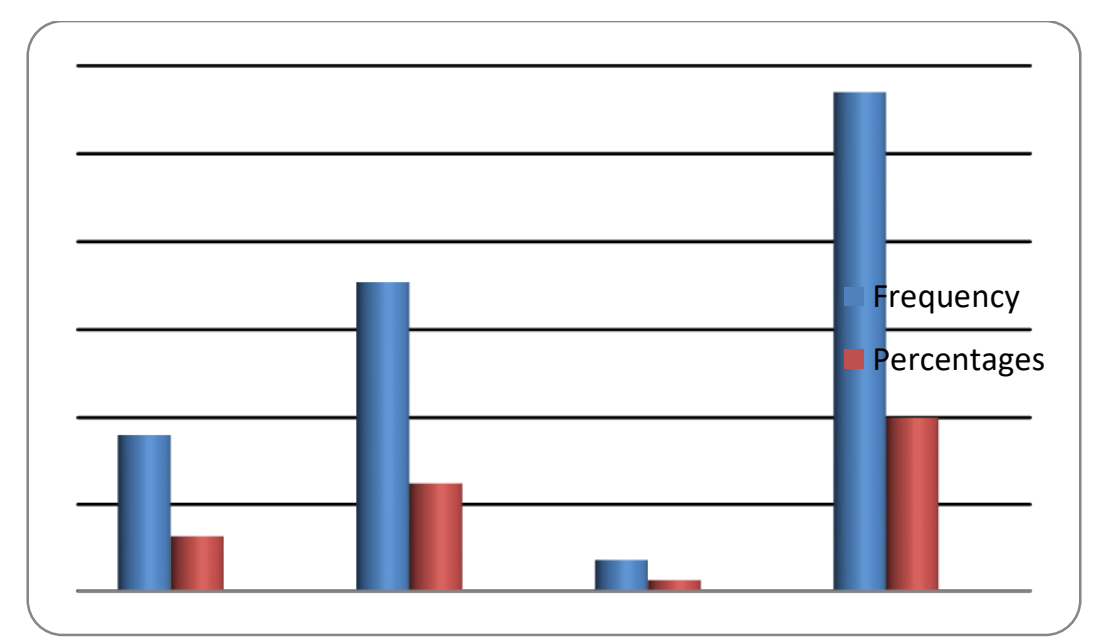

Fig 4:

Source: Field work 2021 
Table 6: Family Member that Run Business

\begin{tabular}{|l|c|l|}
\hline Category & Frequency & Percentages \\
\hline Father & 255 & 89.5 \\
\hline Mother & 22 & 7.7 \\
\hline Relatives & 8 & 2.8 \\
\hline Total & 285 & 100 \\
\hline
\end{tabular}

Source: Field work 2021

Table 6 shows family member that run business which indicated that father has 255(89.5\%), mother 22(7.7\%) while relative that run business shows $8(2.8 \%)$. This implies that father have the highest number of respondents, with the least coming from mother and relatives. The chart below illustrated it.

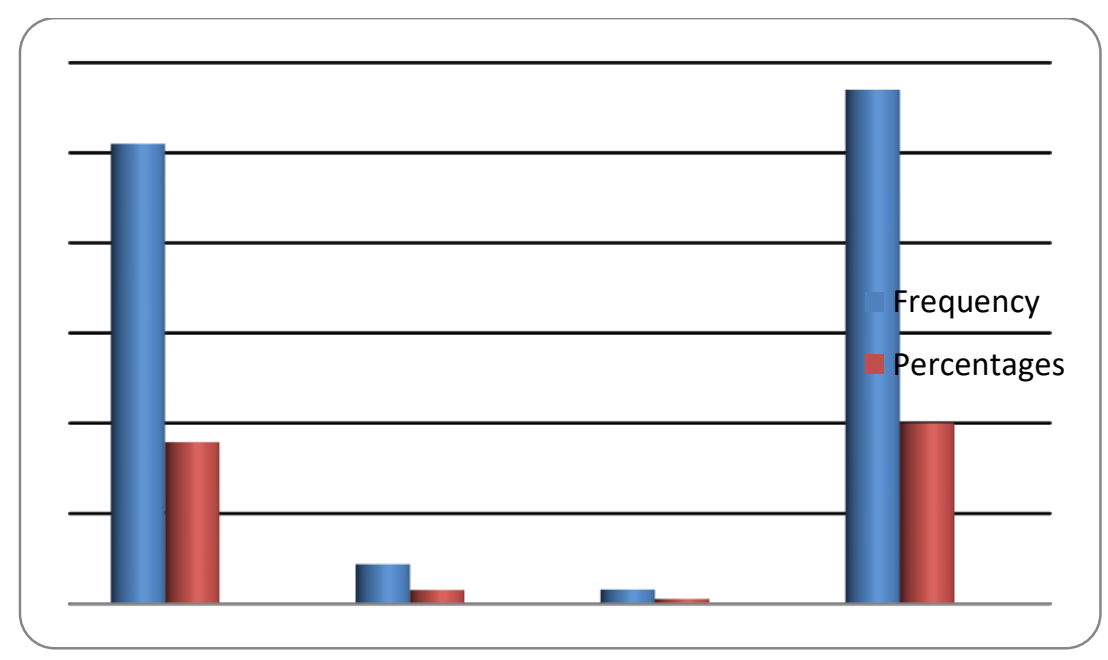

Fig 5:

Source: Field work 2021

Table 7: Role Model

\begin{tabular}{|l|c|c|}
\hline Category & Frequency & Percentages \\
\hline Father & 233 & 81.8 \\
\hline Mother & 32 & 11.2 \\
\hline Relatives & 20 & 7.0 \\
\hline Total & 285 & 100 \\
\hline
\end{tabular}

Source: Field work 2021

Role model refers to learning by examples rather than direct experience, the individual students adopt the behaviour by informal and unintentional observation in the family setting are considered to be an importance factor for entrepreneurial intention. Table 7 shows role model of father $233(81.87 \%)$, mother $32(11.2)$, relatives $20(7.0 \%)$ were the frequency and percentage of respondents. This also will be illustrated on the chart below. 


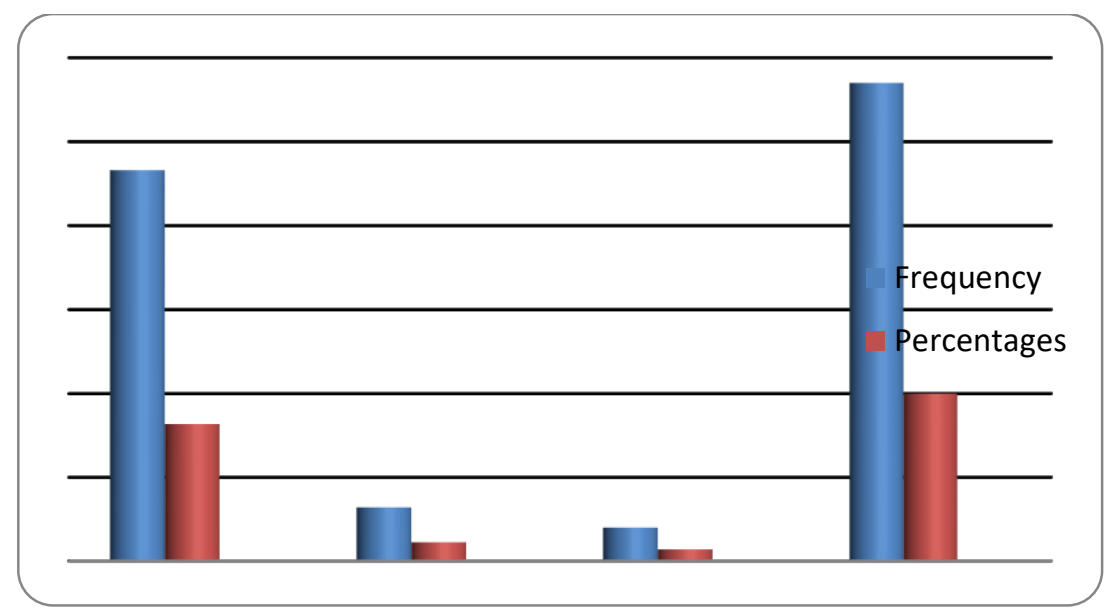

Fig 6:

Source: Field work 2021

Table 8: Schools/Faculties.

\begin{tabular}{|l|l|l|}
\hline Category & Frequency & Percentages \\
\hline Accountancy & 235 & 28.7 \\
\hline Banking and Finance & 88 & 10.8 \\
\hline Business Administration and Management & 135 & 16.5 \\
\hline Marketing & 64 & 7.8 \\
\hline Office Technology and Management & 38 & 4.6 \\
\hline Public Administration & 258 & 31.5 \\
\hline Total & 818 & 100 \\
\hline
\end{tabular}

Source: Field work 2021

Table 8 shows Accountancy 235(28.7\%), Banking and Finance 88(10.8), Business Administration and Management 135(16.5), Marketing 64(7.8), Office Technology and Management 38(4.6) and Public Administration 258(31.5) where the respondent from the department. This implies that Public Administration have the highest number of respondents, with the least from Office Technology and Management department. This chart below illustrated it.

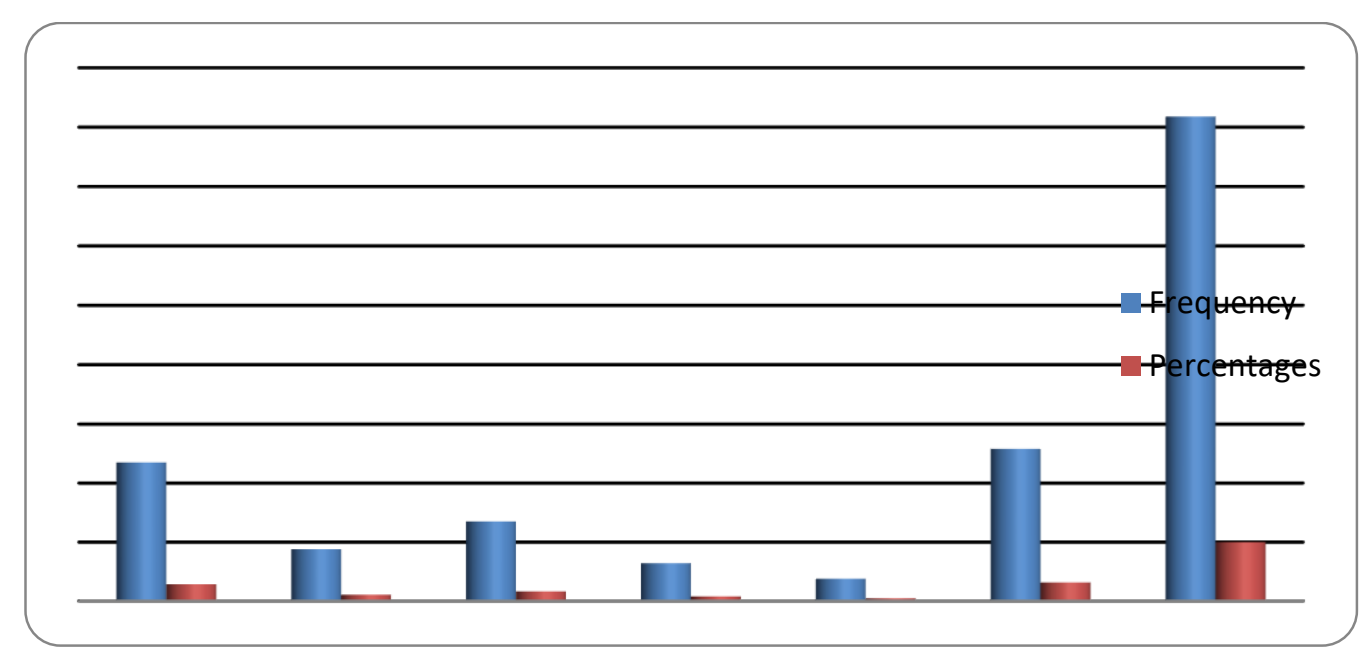




\section{Fig 7:}

Source: Field work 2021

Research Question Two: To what extent does Attitude influence entrepreneurial intention of Higher National Diploma students?

The analysis in Table 9 which was used to answer research question two revealed the overall grand mean responses of Higher National Diploma students' of 3.56 on attitudes. On the questionnaire items mean rating on attitude of Higher National Diploma students towards entrepreneurial intentions indicated that all the 10 items were to a High Extent except item 5 with mean of 3.35 and 10 with mean of 3.38. This implies that, attitude have influence on Higher National Diploma students.

Table 9: Mean score on the extent to which attitude influence entrepreneurial intention of Higher National Diploma students

\begin{tabular}{llll}
\hline S/N & ITEMS & Mean & Remarks \\
\hline 1 & $\begin{array}{l}\text { If I had opportunity and resources, I would love to } \\
\text { start a business }\end{array}$ & 3.85 & High Extent \\
2 & $\begin{array}{l}\text { Being an entrepreneurial would give me great } \\
\text { satisfaction }\end{array}$ & 3.56 & High Extent \\
3 & $\begin{array}{l}\text { Being and entrepreneur implies more advantages } \\
\text { than disadvantages to me }\end{array}$ & 3.67 & High Extent \\
4 & $\begin{array}{l}\text { Amongst various option I would rather be } \\
\text { anything but an entrepreneur }\end{array}$ & 3.50 & High Extent \\
5 & $\begin{array}{l}\text { A career as an entrepreneur is totally attractive to } \\
\text { me }\end{array}$ & 3.35 & Moderately Extent \\
6 & $\begin{array}{l}\text { If I start up a business I will have power to make } \\
\text { decision }\end{array}$ & 3.76 & High Extent \\
7 & $\begin{array}{l}\text { I will have authority if I start p a business of my } \\
\text { own }\end{array}$ & 3.48 & High Extent \\
\hline $\begin{array}{l}\text { I will be able to choose my own tasks if I start up } \\
\text { a business }\end{array}$ & 3.57 & High Extent \\
$\begin{array}{l}\text { I will choose to start p a business so as to be } \\
\text { independence. }\end{array}$ & 3.52 & High Extent \\
10 & $\begin{array}{l}\text { To be my own boss, then I will choose to start up } \\
\text { a business }\end{array}$ & 3.38 & Moderately Extent \\
Grand Mean
\end{tabular}

Source: Field work 2021

Research Question Three: To what extent does a subjective norm influence entrepreneurial intention of Higher National Diploma students?

Table 10 below shows an overall grand mean score of 3.47 on subjective norms on five point Likert scale of measurement to a Moderately extent that subjective norms influence entrepreneurial intentions of Higher National Diploma students'. Notwithstanding, family approval, colleagues approval, decision to personal choice of starting a business and personal 
choice of promoting a business to a high extent influenced their subjective norms in their entrepreneurial intentions of students.

Table 9: Mean scores on the extent to which subjective norms influence entrepreneurial intention of Higher National Diploma students

\begin{tabular}{|c|c|c|c|}
\hline $\mathrm{S} / \mathrm{N}$ & ITEMS & Mean & Remarks \\
\hline 1 & $\begin{array}{l}\text { My friend would approve of my decision to start a } \\
\text { business ventures }\end{array}$ & 3.29 & $\begin{array}{l}\text { Moderately } \\
\text { Extent }\end{array}$ \\
\hline 2 & $\begin{array}{l}\text { My immediate family would approve of my decision to } \\
\text { start a business }\end{array}$ & 3.80 & High Extent \\
\hline 3 & $\begin{array}{l}\text { My colleagues would approve of my decision to start a } \\
\text { business ventures }\end{array}$ & 3.53 & High Extent \\
\hline 4 & $\begin{array}{l}\text { The culture of entrepreneur in out institution is } \\
\text { favourable to societal development }\end{array}$ & 3.41 & $\begin{array}{l}\text { Moderately } \\
\text { Extent }\end{array}$ \\
\hline 5 & $\begin{array}{l}\text { In my country, entrepreneurial activities is considered to } \\
\text { be worthwhile, despite the risks involve }\end{array}$ & 3.47 & $\begin{array}{l}\text { Moderately } \\
\text { Extent }\end{array}$ \\
\hline 6 & $\begin{array}{l}\text { I will choose to start } \mathrm{p} \text { a business so as to participate in a } \\
\text { social environment }\end{array}$ & 3.52 & High Extent \\
\hline 7 & $\begin{array}{l}\text { To be a member of a social 'milieu' then, I will choose to } \\
\text { start } \mathrm{p} \text { a business }\end{array}$ & 3.43 & $\begin{array}{l}\text { Moderately } \\
\text { Extent }\end{array}$ \\
\hline 8 & $\begin{array}{l}\text { I will choose to start } \mathrm{p} \text { a business so as to have } \\
\text { opportunity for career progress }\end{array}$ & 3.29 & $\begin{array}{l}\text { Moderately } \\
\text { Extent }\end{array}$ \\
\hline \multirow[t]{2}{*}{9} & $\begin{array}{l}\text { I will choose to start up a business so as to promotion a } \\
\text { business }\end{array}$ & 3.52 & High Extent \\
\hline & Ground Mean & 3.47 & $\begin{array}{l}\text { Moderately } \\
\text { Extent }\end{array}$ \\
\hline
\end{tabular}

Source: Field work 2021

Research Question Four: To what extent does perceived behavioural norms influence entrepreneurial intention of Higher National Diploma students.

Table 11 revealed an overall grand mean score of 3.51 High extent on perceived behavioural norms that influence entrepreneurial intention of National Diploma students. Notwithstanding, practical details needed to start a business mean score of (3.18), skills acquisition mean score of (3.38) and easy to start own business mean score of (3.48) to a moderately extent influenced their perceived behavioural norms in their entrepreneurial intentions indicated that 7 items were to a high extent influence their entrepreneurial intentions. While item 4,7 and 8 indicated the influence of perceived behavioural norms to a moderately extent. This implies that, all the respondents agreed that perceived behavioursl norms have influence on their entrepreneurial intentions 
Table 11: Mean scores on the extent to which perceived behavioural norms influence entrepreneurial intention of Higher National Diploma students

\begin{tabular}{|c|c|c|c|}
\hline $\mathrm{S} / \mathrm{N}$ & ITEMS & Mean & REMARKS \\
\hline 1 & Starting a firm and keeping it viable would be easy for me & 3.67 & High Extent \\
\hline 2 & $\begin{array}{l}\text { I would be able to control the creation process of a new } \\
\text { business ventures }\end{array}$ & 3.53 & High Extent \\
\hline 3 & $\begin{array}{l}\text { If I tried to start a business, I would have a high chance of } \\
\text { being successful }\end{array}$ & 3.59 & High Extent \\
\hline 4 & $\begin{array}{l}\text { I know all about the practical detail needed to start a } \\
\text { business ventures }\end{array}$ & 3.18 & $\begin{array}{l}\text { Moderately } \\
\text { Extent }\end{array}$ \\
\hline 5 & $\begin{array}{l}\text { To start my own firm would probably be the best way for } \\
\text { me to take advantage of my education }\end{array}$ & 3.62 & High Extent \\
\hline 6 & $\begin{array}{l}\text { I am confidence that I would succeed if I start my own } \\
\text { business }\end{array}$ & 3.62 & High Extent \\
\hline 7 & I have the skills required to succeed as an entrepreneur & 3,38 & $\begin{array}{l}\text { Moderately } \\
\text { Extent }\end{array}$ \\
\hline 8 & It would be easy for me to start my own business & 3.48 & $\begin{array}{l}\text { Moderately } \\
\text { Extent }\end{array}$ \\
\hline 9 & $\begin{array}{l}\text { To start my own business would probably be the best way } \\
\text { for me to take advantage of my education }\end{array}$ & 3.57 & High Extent \\
\hline & Ground Mean & 3.51 & High Extent \\
\hline
\end{tabular}

Source: Field work 2021

Research Question Five: To what extent does closer valuation influence entrepreneurial intention of Higher National Diploma students?

Table 12 shows the grand mean of 3.64 on closer valuation to a High Extent influence of closer valuation on student's entrepreneurial intentions. Notwithstanding, students' immediate family approval of decision to start up a business have mean score of (3.48), creating opportunity of running one's business mean score of (3.33) and persistence in running one's business Mean score of (3.48) to a moderately extent influence students entrepreneurial intentions. This result indicated that closer valuation could also influence entrepreneurial intention of students 
Table 12: Mean scores on the extent to which closer valuation influence entrepreneurial intention of Higher National Diploma students

\begin{tabular}{llll}
\hline S/N & ITEMS & Mean & Remarks \\
\hline 1 & $\begin{array}{l}\text { There is a well functioning support infrastructure in place to } \\
\text { support the start up of new firms }\end{array}$ & 3.59 & High Extent \\
2 & $\begin{array}{l}\text { I know many people in my institutions who have successful } \\
\text { started their own firm. }\end{array}$ & 3.71 & High Extent \\
3 & $\begin{array}{l}\text { My colleague would approve of my decision to start a business } \\
\text { In my institution, people are actively encouraged to pursue } \\
\text { their own ideas }\end{array}$ & 4.56 & High Extent \\
5 & $\begin{array}{l}\text { In my institutions, you get to meet lots of people with good } \\
\text { ideas for a new firms }\end{array}$ & 4.00 & High Extent \\
6 & $\begin{array}{l}\text { My immediate family would approve of my decision to start a } \\
\text { business }\end{array}$ & 3.48 & High Extent \\
7 & $\begin{array}{l}\text { I will make every opportunity to start and run my own } \\
\text { business }\end{array}$ & 3.33 & High Extent \\
8 & $\begin{array}{l}\text { My friend would approve of my decision to start a business } \\
\text { Starting a business and keeping it viable would be very easy for } \\
\text { me. }\end{array}$ & 3.57 & High Extent \\
& $\begin{array}{l}\text { Grand Mean } \\
\text { High Extent }\end{array}$ & High Extent \\
\hline
\end{tabular}

Source: Field work 2021

Research Question 13: To what extent does social valuation influence entrepreneurial intention of Higher National Diploma students?

The result in Table 13 revealed an overall grand mean (3.64) on social valuation. On the questionnaire, indicated that all the 8 items were to a high extent influence entrepreneurial intention of Higher National Diploma students'. The result further shows that only item 6 out of 8 items on social valuation revealed that the students' immediate family values with the mean score of (3.18) which are to a Moderately Extent could influence entrepreneurial intentions. 
Table 13: Mean scores on the extent to which social valuation influence the entrepreneurial intention of Higher National Diploma students

\begin{tabular}{llll}
\hline S/N & ITEMS & Mean & Remarks \\
\hline 1 & $\begin{array}{l}\text { The culture of entrepreneur in highly favourable to } \\
\text { societal development }\end{array}$ & 3.77 & High Extent \\
2 & $\begin{array}{l}\text { In my country, entrepreneurial activities is considered } \\
\text { to be worthwhile, despite the risks }\end{array}$ & 3.82 & High Extent \\
3 & $\begin{array}{l}\text { It is commonly thought that entrepreneur takes } \\
\text { advantages of others }\end{array}$ & 3.53 & High Extent \\
4 & $\begin{array}{l}\text { The entrepreneur's role in the economy is generally } \\
\text { valued my students in my country. }\end{array}$ & 4.00 & High Extent \\
5 & $\begin{array}{l}\text { Most students in my institutions considered it } \\
\text { acceptable to be an entrepreneur. }\end{array}$ & 3.50 & High Extent \\
6 & $\begin{array}{l}\text { My immediate family values entrepreneurial activities } \\
\text { above other activities and career. } \\
\text { My friend value entrepreneurial activities above other }\end{array}$ & 3.18 & Moderately Extent \\
7 & $\begin{array}{l}\text { activities and careers, } \\
\text { If I become an entrepreneur, my family would } \\
\text { consider it to be good }\end{array}$ & 3.56 & High Extent \\
Grand Mean & 3.64 & High Extent \\
\hline
\end{tabular}

Source: Field work 2021

Null Hypothesis One: Attitude has no significant influence on entrepreneurial intention of Higher National Diploma Students.

Table 14 display the result of the independent variable in the prediction of the dependent variable (Entrepreneurial Intention). Since the regression weight $(\beta)$ indicates the relative contribution of the independent variable to the dependent variable, the result show that attraction is a significant predictor of entrepreneurial intention of students $(\beta=.343, \mathrm{t}=$ 8.728. $\mathrm{P}<.05)$. Because the sign associated with the regression weight $(\beta)$ indicate the direction of prediction. It follow that the relationship between attitude and entrepreneurial intention is positive and significant. The result means that as the $\mathrm{E} 1=\mathrm{a}+\beta_{1} \mathrm{X}_{1}$ and $\mathrm{a}$ is constant and $\beta_{1}$ are coefficient to estimate. $\mathrm{E} 1=1.999+, 343$ where $\mathrm{E} 1=$ entrepreneurial intention and $\mathrm{X}_{1}=$ attitude

Table 14: Linear regression of coefficients for the standard error of the estimate on extent of attitude among Higher National Diploma students'.

\begin{tabular}{llrrrrr}
\hline \multirow{2}{*}{ Model } & \multicolumn{2}{c}{ Coefficients $^{\mathbf{a}}$} & & \\
& & \multicolumn{2}{c}{$\begin{array}{c}\text { Unstandardized } \\
\text { Coefficients }\end{array}$} & $\begin{array}{c}\text { Standardized } \\
\text { Coefficients } \\
\text { Beta }\end{array}$ & T & Sig. \\
& $\mathrm{B}$ & Std. Error & Beta & \\
\hline 1 & (Constant) & 1.999 & .163 & & 12.282 & .000 \\
& Attitude & .400 & .046 & .343 & 8.728 & .000
\end{tabular}

Dependent variable (Entrepreneurial Intention) 
Null Hypothesis Two: Subjective Norms has no significant influence on entrepreneurial intention of Higher National Diploma Students.

Table 15 Also display the result of the independent variable in the prediction of the dependent variable (Entrepreneurial Intention). Since the regression weight $(\beta)$ indicates the relative contribution of the independent variable to the dependent variable, the result show that subjective norm is significant predictor of entrepreneurial intention of students $(\beta=$ $.199, \mathrm{t}=4.864 . \mathrm{P}<.05)$. Because the sign associated with the regression weight $(\beta)$ indicate the direction of prediction. It follow that the relationship between subjective norm and entrepreneurial intention is positive and significant. The result mean that as the $E I=a+\beta_{1}$ $\mathrm{X}_{1}$ and $\mathrm{a}$ is constant and $\beta_{1}$ are coefficient to estimate. $\mathrm{EI}=2.571+0,199$ where $\mathrm{EI}=$ Entrepreneurial intention, $\mathrm{X}_{1}=$ Subjective Norm

Table 15: Linear regression coefficients for the standard error of the estimate of extent of subjective norms among the National Diploma students'.

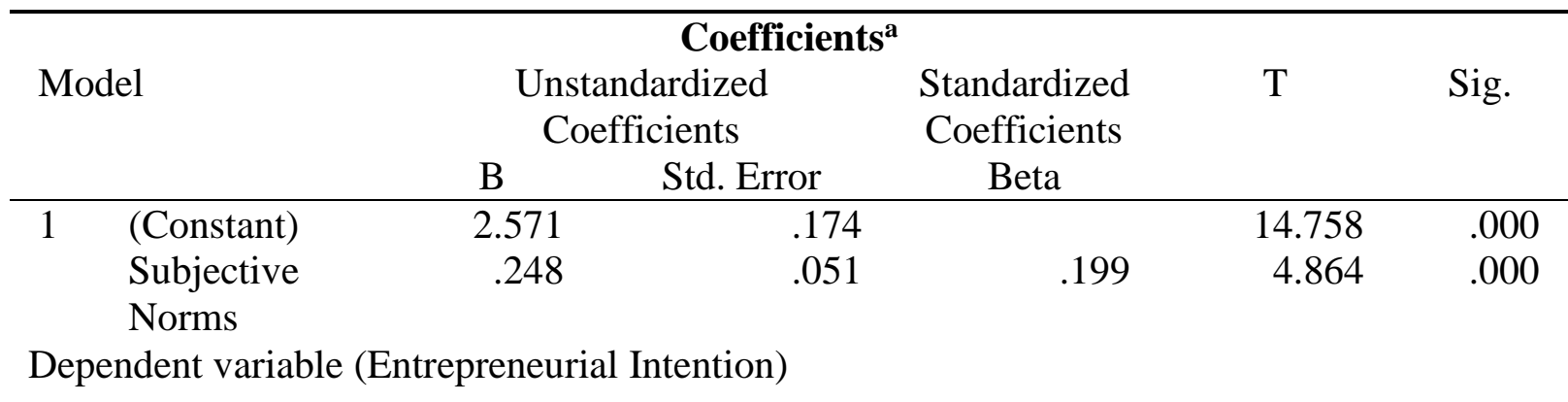

Null Hypothesis Three: Perceived Behavioural Control has no significant influence on entrepreneurial intention of Higher National Diploma Students.

Table 16 display the result of the independent variable in the prediction of the dependent variable (Entrepreneurial Intention). Since the regression weight $(\beta)$ indicates the relative contribution of the independent variable to the dependent variable, the result show that perceived behavioural is significant predictor of entrepreneurial intention of students $(\beta=$ $.552, \mathrm{t}=15.828, \mathrm{P}<.05)$. Because the sign associated with the regression weight $(\beta)$ indicate the direction of prediction. It follow that the relationship between perceived behavioural and entrepreneurial intention is positive and significant. The result mean that as the $E I=$ at $\beta_{1} X_{1}$ and $\mathrm{a}$ is constant and $\beta 1$ are coefficient to estimate. $\mathrm{EI}=1.641+0.552$ where $\mathrm{EI}=$ Entrepreneurial Intention $\mathrm{X}_{1}=$ perceived behavioural.

Table 16: Linear regression coefficients for the standard error of the estimate on extent of perceived behavioural factors among Higher National Diploma students'.

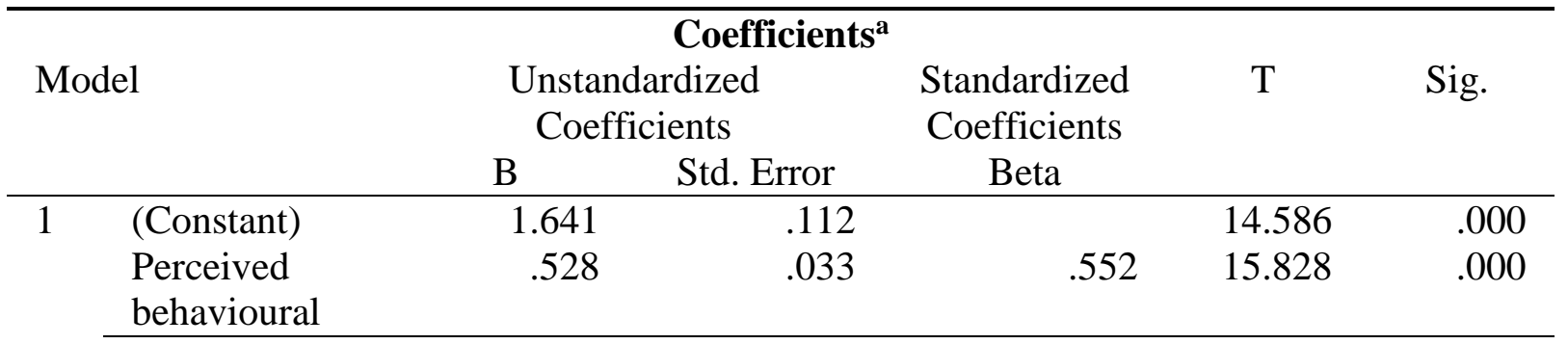


Dependent variable (Entrepreneurial Intention)

Null Hypothesis Four: Closer Valuation Norms has no significant influence on entrepreneurial intention of Higher National Diploma Students.

Table 17 Also display the result of the independent variable in the prediction of the dependent variable (Entrepreneurial Intention). Since the regression weight $(\beta)$ indicates the relative contribution of the independent variable to the dependent variable, the result show that closer valuation is significant predictor of entrepreneurial intention of students $(\beta=$ $.428, \mathrm{t}=11.346, \mathrm{P}<.05)$. Because the sign associated with the regression weight $(\beta)$ indicate the direction of prediction. It follow that the relationship between closer valuation and entrepreneurial intention is positive and significant. The result mean that as the $E I=a+\beta_{1} X_{1}$ and $\mathrm{a}$ is constant $\beta 1$ are coefficient to estimate. EI $=1.770+0.428$ where $\mathrm{EI}=$ Entrepreneurial Intention X1 = Closer valuation

Table 17: Linear regression coefficients for the standard error of the estimate on extent of closer valuation factors among the National Diploma students'.

\begin{tabular}{|c|c|c|c|c|c|}
\hline \multirow[t]{2}{*}{ Model } & Unst & $\begin{array}{l}\text { efficients } \\
\text { ardized }\end{array}$ & Standardized & \multirow[t]{2}{*}{$\mathrm{T}$} & \multirow[t]{2}{*}{ Sig. } \\
\hline & B & Std. Error & Beta & & \\
\hline $1 \quad$ (Constant) & 1.770 & .145 & & 12.170 & .000 \\
\hline Closer Valuation & .492 & .043 & .428 & 11.346 & .000 \\
\hline
\end{tabular}

Dependent variable Entrepreneurial Intention

Null Hypothesis Five: Social Valuation has no significant influence on entrepreneurial intention of Higher National Diploma Students.

Table 18 display the result of the independent variable in the prediction of the dependent variable (Entrepreneurial Intention). Since the regression weight $(\beta)$ indicates the relative contribution of the independent variable to the dependent variable, the result show that social valuation is significant predictor of entrepreneurial intention of Polytechnic students $(\beta=$ $.286, \mathrm{t}=7.143, \mathrm{P}<.05)$. Because the sign associated with the regression weight $(\beta)$ indicate the direction of prediction. It follow that the relationship between social valuation and entrepreneurial intention is positive and significant. The result means that as the EI $=\mathrm{a}+$ $\beta_{1} X_{1}$ and $a$ is constant and $\beta 1$ are coefficient to estimate. $E I=1.935+0.286$ where $E I=$ Entrepreneurial Intention, $\mathrm{X}_{1}=$ Social Valuation. 
Table 18: Linear regression coefficients for the standard error of the estimate of extent of social valuation factors among Higher National Diploma students'.

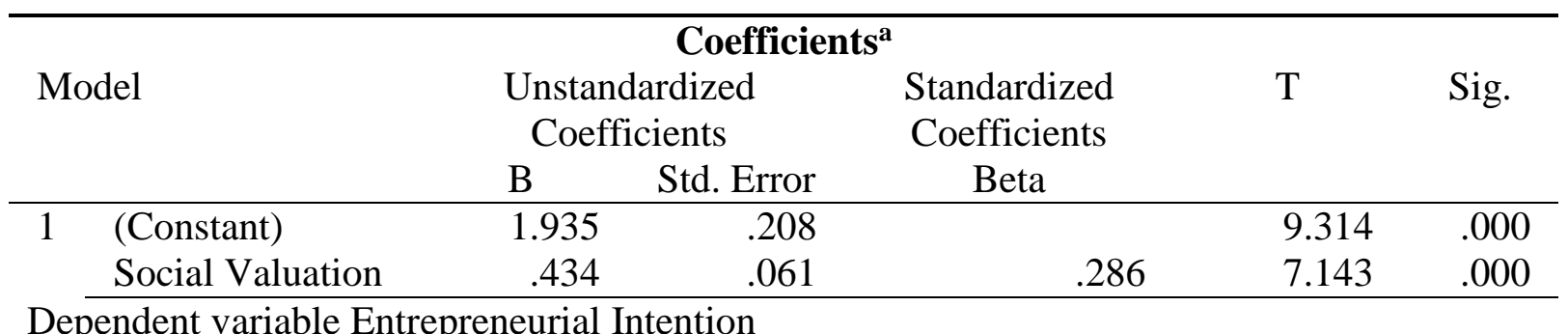

\section{Summary of Findings}

The following are the findings of the study on analysis of data, which answer the research questions and the null hypotheses.

1. The results of research question one revealed that demographic characteristic have positive influence on entrepreneurial intention of Higher National Diploma students.

2. The results of research question two and test of null hypothesis one shows that attitude has a significant and positive influence on entrepreneurial intention of Higher National Diploma students'.

3. The result of research question three and test of null hypothesis two revealed that subjective norms is one of the good predictor of entrepreneurial intention of Higher National Diploma students' of Polytechnic Business Studies.

4. The result of research question four and test of null hypothesis three revealed that perceived behavioural control has a significant and positive influence on entrepreneurial intentions of Higher National Diploma students'.

5. The result of research question five and test of null hypothesis four also revealed that closer valuation has a significant influence in successfully determining or predicting the entrepreneurial intention of Higher National Diploma students.

6. The result of research question six and test of null hypothesis five revealed that social valuation is one of the determinants of entrepreneurial intention of Higher National Diploma students.

\section{Conclusion}

This study focus on determinants of entrepreneurial intentions among the Higher National Diploma Students. Therefore, the result of the findings revealed that demographic characteristic, attitude, subjective norms, perceived behavioural control, closer valuation and social valuation has a significant and positive influence on entrepreneurial intentions.

\section{Recommendation}


The following recommendations were proffered based on findings of the study and their implications therefore recommended that, all the stakeholder such as government agency, policy makers, school authorities, and parents should create enabling environment that will help the students to developed positive attitude towards entrepreneurial development.

\section{References}

1) Ajzen, I. (1991). The Theory of Planned Behaviour, Organizational Behaviour and HumanDecision Processes, 50, 179 - 211.

2) Choo, S, \& Wong M, (2000), Entrepreneurial Intention, Triggers and Barriers to New venturecreations in Singapore. Singapore Management Review, 28(i2), 47-64.

3) Drucker, P.F. (1985), Innovation and Entrepreneurship: Practice and Principles, USA: Harper -Row.

4) Fakae, D.B., (2005). Technical Education: An Overview of the learning process. Capacity Building of workshop for Lecturers of Polytechnics and Monotechnics in Nigerian for Higher Competence and Productivity Education Trust Funds.

5) Federal Republic of Nigeria (1988). National Policy on Education, Lagos Nigeria

6) Fuduric, N. (2008). The Sources of Entrepreneurial Opportunities: Individuals \& the Environment. Doctoral Research Paper. Department of Planning and Development, Aalborg University.

7) Hair, J.F., Black, B., Babin, B. Anderson, R.E \& Tatham R. L., (2007). Multivariate data analysis, Upper Saddle River, NJ Prentice Hall.

8) Henry, R., F \& Kathleen D. W., (2003). Entrepreneurial Motivation: A study of Hong Kong MBA students. Journal of Managerial Psychology, 11(3), 12-25.

9) Izedonmi, P.F \& Okafor, C., (2010). The Effect of Entrepreneurship Education on Students'entrepreneurial Intention. Global Journal of Management and Business Research 10(6), 49-60.

10) Krueger, N. Reillly, M \& Carsrud, A (2005) Competing models of entrepreneurial intention. Journal of Business Venturing, 15, 5-6,411-432.

11) Kolvereid. L \& Moen. O. (1997). Entrepreneurship Among Business Graduate: Does a Majorin Entrepreneurship Make a Difference? Journal of Business Venturing 2(94) 154-160.

12) Nabi, G., Holdeni, N. \& Linan, F. (2011). Graduate Entrepreneurship in the Developing World: Intention, Education and Development, Journal of Education and Training 23(5), 325-334, http//ds.doi.org/10.1108/00400911111147668.

13) Oyebola, O.T (2010) Entrepreneurship Education, key to solving graduate unemployment, an article published in the Vanguard Newspaper Nigeria, Available on www.vanguardngr.com/2010/08/entreprenruship-education-key-to-solvinggraduate unmployment-expert.Accessed July 17,2012

14) Parker, S. C., (2004). The Economics of Self-Employment and Entrepreneurship. International. Journal of Academic Research in Business and Social Science. 2 (1). 
15) Raimi., L., Towobola, W.L \& Kolade, T.T and Fadipe, A.O (2011) Prospects and challenges of teaching accounting and entrepreneurship and economic development in Nigeria Edited by Dr Kolawole Subair, Olad Publishers Nigeria Limited, Kwara Nigeria. 